\title{
Pengaruh Jenis Media dan Pakan Terhadap Kualitas Pupuk Organik Cair Cacing Tanah (Lumbricus Rubellus)
}

\author{
Rusniyati, Bambang S. Lautt, Adi Jaya, Emmy Uthanya Antang, Wahyu Widyastuti \\ dan Muhammad Saleh \\ Fakultas Pertanian, Universitas Palangka Raya \\ Email : adijaya@agr.upr.ac.id
}

\begin{abstract}
Abstrak
Tujuan penelitian ini adalah: 1) untuk mengetahui adanya interaksi antara jenis media dan jenis pakan terhadap kualitas pupuk organik cair pada kompos cacing tanah Lumbricus rubellus, 2) untuk mengetahui adanya pengaruh jenis pakan terhadap kualitas hasil pupuk organik cair dari kompos cacing tanah Lumbricus rubellus, 3) untuk mengetahui adanya pengaruh jenis media terhadap kualitas hasil pupuk organik cair pada kompos cacing tanah Lumbricus rubellus. Penelitian ini menggunakan Rancangan Acak Lengkap faktorial 4x3 dengan 3 ulangan. Faktor perlakuan pertama G1 : Pupuk Kandang Kotoran Sapi 100\% (1,4 kg), G2 : Kombinasi Media Pupuk Kandang Kotoran Sapi 50\% (0,7 kg) dengan Tanah Gambut faktor perlakuan kedua P1 : Ampas Tahu = 150 g, P2: Rumen Sapi $=100$ g. Parameter pengamatan yang digunakan yaitu Bobot akhir cacing, pH, NO3, NO2, P, K, NH3 dan N. Hasil yang didapatkan adanya interaksi antara jenis media dan pakan terhadap kualitas pupuk organik cair pada kompos cacing tanah Lumbricus rubellus terhadap parameter bobot akhir cacing tanah Lumbricus rubellus dengan kombinasi terbaik terdapat pada perlakuan kombinasi media pupuk kandang kotoran sapi dengan tanah gambut (155,77 gram) dan pada parameter $\mathrm{pH}$. Terdapat pengaruh yang nyata pada jenis media terhadap kualitas hasil pupuk organik cair pada kompos cacing tanah Lumbricus rubellus tehadap parameter K faktor tunggal perlakuan kombinasi media pupuk kandang kotoran sapi $(269,23 \mathrm{mg} / \mathrm{l})$ dan terhadap parameter suhu dipagi hari pada faktor tunggal perlakuan kombinasi media pupuk kandang kotoran sapi dengan tanah gambut $\left(26,50{ }^{\circ} \mathrm{C}\right)$, dan siang hari terdapat pada faktor tunggal perlakuan media kombinasi media pupuk kandang kotoran sapi dengan tanah gambut $\left(29,26^{\circ} \mathrm{C}\right)$. Sedangkan yang tidak berpengaruh nyata terhadap parameter senyawa $\mathrm{NO} 3$, senyawa $\mathrm{NO} 2$, unsur $\mathrm{P}$, senyawa NH3, dan unsur N. Terdapat pengaruh yang nyata pada jenis pakan terhadap kualitas hasil pupuk organik cair dari kompos cacing tanah Lumbricus rubellus terhadap parameter suhu dipagi hari pada faktor tunggal perlakuan pakan rumen sapi $\left(26,51^{\circ} \mathrm{C}\right)$.
\end{abstract}

Kata kunci : Cacing Lumbricus rubellus, Pupuk Kandang Kotoran Sapi, TanahGambut, Ampas Tahu, Rumen Sapi, Pupuk Cair Kompos Cacing.

\section{Pendahuluan}

Media atau sarang merupakan tempat tinggal sekaligus makanan cacing tanah dan didalam media tersebut cacing tanah melakukan segala aktivitasnya seperti bergerak, makan, tumbuh, dan bereproduksi. Oleh karena itu, bahan media harus memenuhi syarat sebagai tempat hidup dan sebagai makanan (Pangkulun, 2010).

Pertumbuhan cacing tanah sangat bergantung pada jenis pakannya, pertumbuhan cacing tanah akan meningkat bila pakan tersebut banyak mengandung bahan organik (Suin, 1997). Distribusi bahan organik dalam tanah berpengaruh terhadap cacing tanah, karena terkait dengan sumber nutrisinya sehingga pada tanah miskin bahan organik hanya sedikit jumlah cacing tanah yangdijumpai. Bobot cacing tanah sangat dipengaruhi oleh kondisi media dan ketersediaan nutrisi (Pangkulun, 1999). Semakin berkurangnya ketersediaan nutrisi dalam media akan menyebabkan aktifitas metabolisme menurun sehingga terjadi penurunan energi hasil metabolisme (Wulandari, 2000). Bobot cacing tanah sangat dipengaruhi oleh kondisi media dan ketersediaan nutrisi (Pangkulun, 1999).

Pakan yang diberikan kepada cacing akan menentukan jumlah dan kualitas pupuk yang dihasilkan (Setiadji dan Hartati, 2012). Secara umum yang dapat dijadikan bahan pakan cacing berupa limbahlimbah organik, seperti limbah sayuran, serbuk gergaji atau sisa media jamur, limbah hijauan, kotoran ternak, pelepah, daun, batang dan bongkol pisang, limbah jerami padi dan ampas tahu (Rozaq dan Novianto, 2010 ).

Pupuk organik cair merupakan pupuk berbentuk cairan dan umumnya hasil ekstrak bahan organik yang telah dilarutkan dengan pelarut seperti air, alkohol, atau minyak. Pupuk organik cair lebih mudah diserap oleh tanaman dengan penyemprotan terutama melalui daun karena unsur-unsur didalamnya 
sudah terurai sehingga dapat disebut sebagai pupuk daun. Selain itu dapat juga diaplikasikan di sekitar tanaman (Djuarnani $d k k, 2005$ ). Jenis cacing tanah yang biasa digunakan dalam pembuatan kompos adalah Lumbricus rubellus. Cacing Lumbricus. rubellus sering ditemukan di bawah timbunantimbunan dedaunan atau timbunan kotoran ternak dan sering hidup di lapisan yang mendekati permukaan tanah. Pupuk organik cair yang dihasilkan berupa ekstrak lindi (cairan)hasil perombakan metabolisme cacing, media tumbuh atau sisa pakan cacing hasil dari proses pengomposan (Djuarnani $d k k, 2005)$. Lindi (cairan) tersebut mengandung unsur hara baik unsur hara mikro maupun makro yang berguna bagi pertumbuhan tanaman diantaranya penambahan pupuk organik cair cacing inidapat meningkatkan konsentrasi serta penyerapan nitrogen dan kalium oleh tanaman (Mulat, 2003).

Pemanfaatan pupuk organik cair dalam budidaya tanaman diharapkan menjadi salah satu solusi kendala utama yang dihadapi dalam budidaya tanaman di Kalimantan Tengah umumnya berkaitan dengan kondisi lahan yang berupa tanah marginal, baik gambut maupun tanah bersifat padat. Salah satu syarat yang diperlukan bagi pertumbuhan tanaman yang baik adalah tersedianya media tumbuh yang sesuai bagi pertumbuhan tanaman tersebut. Oleh karena itu untuk mengatasi kendala kesuburan tanah pada lahan marginal terutama untuk memperbaiki sifat fisika, kimia dan biologi tanah maka pemberian pupuk organik menjadi sangat penting dilakukan. Pupuk organik selain berperan memperbaiki struktur tanah, ternyata juga mampu menyediakan unsur hara yang diperlukan tanaman terutama sebagai sumber unsur N, P, dan K (Lingga dan Marsono, 2000).Pupuk organik merupakan salah satu pupuk bahan alami yang tidak akan meninggalkan residu pada hasil tanaman sehingga aman bagi kesehatan kita manusia (Musnamar, 2007).

Seiring dengan meningkatnya kesadaran akan resiko yang ditimbulkan oleh penggunaan bahan kimia sintetis dalam produksi pertanian, masyarakat kini semakin arif dalam memilih bahan pangan yang aman bagi kesehatan dan ramah lingkungan. Adanya kesadaran akan akibat yang ditimbulkan tersebut, perhatian kini perlahan mulai bergeser ke pertanian yang berwawasan lingkungan (Piay $d k k$, 2012). Dalam pengembangan lahan marginal seperti tanah gambut, potensi pemanfaatan bahan-bahan produksi yang bersifat organik cukup potensial dilakukan, diantaranya adalah penggunaan pupuk organik.

Tujuan penelitian ini adalah :

1. Untuk mengetahui adanya interaksi antara jenis media dan jenis pakan terhadap kualitas pupuk organik cair pada kompos cacing tanah Lumbricus rubellus

2. Untuk mengetahui adanya pengaruh jenis media terhadap kualitas hasil pupuk organik cair dari kompos cacing tanah Lumbricus rubellus

3. Untuk mengetahui adanya pengaruh jenis pakan terhadap kualitas hasil pupuk organik cair pada kompos cacing tanah Lumbricus rubellus

\section{Bahan dan Metode}

\section{Waktu dan Tempat}

Penelitian ini dilaksanakan pada Bulan Oktober 2019-November 2020. Bertempat di Kebun Percobaan Jurusan Budidaya Pertanian, Fakultas Pertanian Universitas Palangka Raya dan Laboratorium Analitik Universitas Palangka Raya.

\section{Bahan dan Alat}

Bahan yang digunakan pada penelitian ini adalah pupuk kandang kotoran sapi, tanah gambut, limbah pemotongan sapi (rumen sapi), limbah pabrik tahu (ampas tahu), bibit cacing tanah Lumbricus rubellus. Alat yang digunakan untuk pembuatan pupuk organik cair dari kompos cacing tanah Lumbricus rubellus adalah timbangan analitik, baskom plastik ukuran $26 \mathrm{~cm}$ x $19 \mathrm{~cm}$ x $9 \mathrm{~cm}$, kain kasa, potongan batang bambu $5 \mathrm{~cm}$, rak baskom, thermometer dan alat-alat Laboratorium penunjang analisis unsur hara.

\section{Metodologi Penelitian}

Penelitian ini menggunakan Rancangan Acak Lengkap (RAL) faktorial, dengan 2 faktor perlakuan, sebagai berikut Faktor pertama adalah jenis media yang terdiri dari 2 taraf perlakuan (G) yaitu: G1 : Pupuk Kandang Kotoran Sapi 100\% (1,4 kg) dan G2 : Kombinasi Media Pupuk Kandang 
Kotoran Sapi 50\% (0,7 kg) dengan Tanah Gambut 50\% (0,7 kg). Faktor kedua adalah jenis pakan yang terdiri dari 2 taraf perlakuan $(\mathrm{P})$ yaitu : P1 : Ampas Tahu $=150 \mathrm{~g}$ dan P2 : Rumen Sapi $=$ $100 \mathrm{~g}$.

Pada penelitian ini kombinasi perlakuan sebanyak 4 kombinasi dengan masing-masing perlakuan diulang 3 kali sehingga terdapat 12 satuan percobaan, Tata letak satuan percobaan disajikan pada Lampiran, kombinasi perlakuan sepertipada Tabel 1.

Tabel 1. Kombinasi Perlakuan Jenis Media dan Jenis Pakan

\begin{tabular}{|c|c|c|c|c|}
\hline \multirow{2}{*}{$\begin{array}{c}\text { Media } \\
(\mathrm{G})\end{array}$} & \multirow{2}{*}{$\begin{array}{l}\text { Pakan } \\
\text { (P) }\end{array}$} & & Ulangan & \\
\hline & & 1 & 2 & 3 \\
\hline \multirow{2}{*}{ G1 } & $\mathrm{P} 1$ & G1P1 & G1P1 & G1P1 \\
\hline & $\mathrm{P} 2$ & G1P2 & G1P2 & G1P2 \\
\hline \multirow{2}{*}{$\mathrm{G} 2$} & $\mathrm{P} 1$ & G2P1 & G2P1 & $\mathrm{G} 2 \mathrm{P} 1$ \\
\hline & P2 & G2P2 & G2P2 & $\mathrm{G} 2 \mathrm{P} 2$ \\
\hline
\end{tabular}

\section{Pelaksanaan Penelitian}

\section{Pembuatan Rumah Kompos}

Tempat penyimpanan kompos yaitu kandang pengomposan dengan menggunakan cacing ini bertujuan untuk melindungi tempat pengomposan dari gangguan hewan atau hama dan sinar matahari langsung. Kandang pengomposan tersebut harus menggunakan atap dan dinding dan dalam kondisi suhu yang sejuk tersebut terdapat rak atau meja untuk meletakkan bak pengomposan agar aman dari semut, tikus dan hama lain.

\section{Pembuatan Media dan Pakan untuk Budidaya Cacing Tanah Lumbricus rubellus}

a. Media tumbuh cacing dibuat sesuai perlakuan dengan (pupuk kandang kotoran sapi 50\%), (Tanah Gambut 50\%) kemudian diaduk pupuk kandang kotoran sapi dan tanah gambut supaya tercampur rata dan didiamkan selama satu minggu untuk melunakkan media. Media dibuat dalam keadaan lembab.

b. Pakan cacing dari limbah pabrik tahu (ampas tahu) dan limbah pemotongansapi (rumen), bahan tersebut direndam air selama 1 hari 1 malam, untuk mematikan semut dan ulat yang ada pada ampas tahu dan rumen. Setelah selesai perendaman, bahan pakan seperti ampas tahu dan rumen tersebut ditiriskan, kemudian ditimbang dengan berat ampas tahu 150 gram dan rumen 100 gram, pakan yang sudah ditimbang kemudian ditabur diatas permukaan media.

c. Sebanyak 2 buah baskom plastik ukuran $26 \times 19 \times 9(\mathrm{~cm})$, baskom pertama sebagai baskom bawah untuk menampung air cacing dan baskom kedua sebagai baskom bagian atas untuk tempat media cacing. Untuk baskom atas dibuat lubang sebanyak 50 lubang dengan ukuran 2,5 mm agar pupuk cair cacing dari baskom atas dapat menetes ke baskom bawah. Kemudian dipermukaan baskom dibuat lapisan atas dengan kain kasa supaya cacingtidak turun ke baskom bawah.

d. Media cacing diletakkan pada baskom atas, diatas kain kasa dengan ketebalan media $5 \mathrm{~cm}$.

e. Potongan batang bambu diletakan dalam baskom bawah pada masing-masing sisi baskom untuk menyangga baskom atas dan menyusun kedua baskom tersebut yaitu baskom pertama yang masih kosong diletakkan dibawah dari baskom bagian atas yang telah berisi media cacing.

f. Bibit cacing Lumbricus rubellus yang sudah ditimbang dengan timbangan analitik sebanyak 50 gram, dimasukkan ke atas media masing-masing perlakuan yang sudah ditentukan secara merata, setiap perlakuan bibit cacing digunakan sebanyak 50 gram/baskom. Baskom disimpan pada rak atau meja dan letakkan di tempat sejuk, tidak terkena sinar matahari serta aman dari semut, tikus dan hama lainnya.

g. Pembalikan media dilakukan setiap hari dalam satu minggu sebelum bibit cacing dimasukkan agar terjadi aerasi dalam media dan penyiraman media agar terjaga kelembabannya dengan air sebanyak $250 \mathrm{ml}$ secara merata di seluruh permukaan media.

h. Pemberian pakan cacing dengan ampas tahu sebanyak 150 gram dan rumen sebanyak 100 gram. Pakan ampas tahu diberikan 2 kali dalam seminggu, sedangkan untuk pakan rumen diberikan 1 kali 
dalam seminggu. Pakan yang telah direndam dengan air selama satu hari satu malam dengan cara ditebarkan secara merata di atas media.

i. Panen cacing dapat dilakukan saat 35 hari setelah proses pengomposan dan untuk sampel pupuk organik cair terlebih dahulu disaring kemudiandimasukan kedalam botol sprayer yang berukuran 1 liter untuk mengukur volume pupuk organik cair, setelah diukur dimasukan kedalam botol plastik untuk analisis dilaboratorium untuk menentukan Konsentrasi $\mathrm{NO}_{3}, \mathrm{NO}_{2} \mathrm{P}, \mathrm{K}, \mathrm{NH} 3, \mathrm{~N}$ dan pH. Sedangkan untuk media padatan (kascing) terlebih dahulu dipisahkan dengan cacing, kemudian media padatan (kascing) ditimbang dan dimasukan kedalam plastik dan dianalisis di Laboratorium.

\section{Analisis Laboratorium}

Metode analisis laboratorim dalam pelaksanaan penelitian dilanjutkan pada tahap analisis laboratorium untuk mengetahui hasil kandungan hara utama pada pupuk organik cair yang dihasilkan dari vermikompos seperti pada Tabel 2

Tabel 2. Metode Analisis Kualitas Pupuk Organik Cair Hasil Vermikompos

\begin{tabular}{|c|l|l|l|}
\hline No. & Analisis & Metode & Sumber \\
\hline 1. & Nitrat $(\mathrm{NO} 3)$ & Colorimetri & $($ Yang $d k k, 1998)$ \\
\hline 2. & Nitrit(NO2) & Sulfanilamide & (Tachibana, 2000) \\
\hline 3. & Posfor $(\mathrm{P})$ & Spektrofotometer Serapan Atom & (Tachibana, 2000) \\
\hline 4. & Kalium $(\mathrm{K})$ & Spektrofotometer Serapan Atom & (Tachibana, 2000) \\
\hline 5. & Amoniak & Titrasi & (Tachibana, 2000) \\
\hline 6. & Nitrogen & Kjeldahl & (Tachibana, 2000) \\
\hline
\end{tabular}

\section{Parameter Yang Diamati :}

Untuk mengetahui pengaruh dua jenis media dan pakan yaitu dilakukan :

1. Pengukuran suhu dilakukan dengan menggunakan termometer selama 35 hari yaitu pagi pukul 07.00 WIB, siang 13.00 WIB dan sore pukul 16.00 WIB di tempat pembudidayaan cacing tersebut. Pengukuran tersebut dilakukan dengan cara ditancapkan termometer ke bagian atas hingga kedalam sampel media yang telah diberi perlakukan dan ditunggu selama satu menit setelah ditancapkan lalu dicatat hasil pengukuran tersebut dari hari pertama hingga hari terakhir.

2. Pengukuran $\mathrm{pH}$ pupuk organik hasil dari proses pengomposan dilakukan menggunakan $\mathrm{pH}$ meter. Pengukuran dilakukan pada hari terakhir setelah pengomposan. Pengukuran dilakukan dengan cara dicelupkan elektroda kedalam sampel yang diuji dan nilai $\mathrm{pH}$ akan dapat dilihat pada skala pembacaan pada $\mathrm{pH}$ meter. Skala $\mathrm{pH}$ berkisar antara 0 - 14. Sampel dengan $\mathrm{pH}$ kurang dari 7 dianggap asam dan $\mathrm{pH}$ lebih dari 7 dianggap basa. Lalu apabila $\mathrm{pH}$ berhenti di angka 7 dianggap netral.

3. Analisis pupuk organik cair dengan parameter seperti pada Tabel 2.

4. Dilakukan pengamatan terhadap parameter bobot koloni cacing Lumbricus rubellus pada hari ke 35. Cacing dipisahkan dari media kemudian cacing ditimbang untuk mengetahui bobot koloni terakhir.

\section{Analisis Data}

Data yang diperoleh dianalisis dengan analisis ragam dengan menggunakan uji $\mathrm{F}$ taraf $\alpha=5 \%$, apabila terdapat beda nyata dilanjutkan dengan Uji Beda Nyata Jujur (BNJ) pada taraf $\alpha=5 \%$ untuk mengetahui perbedaan antara perlakuan.

\section{Hasil dan Pembahasan}

\section{Bobot Cacing Tanah Lumbricus rubellus}

Pada akhir pembudidayaan cacing tanah Lumbricuss rubellus terlebih dahulu dipisahkan dari media padatan dan dibersihkan setelah itu ditimbang untuk mengetahui bobot cacing tersebut. Penimbangan 
bobot dilakukan dengan timbangan analitik, sehingga didapatkan bobot cacing tanah Lumbricus rubellus selama 35 hari diperoleh hasil yang disajikan pada Tabel 3. Setelah diuji lanjut dengan BNJ taraf 5\% diperoleh hasil yang disajikan pada Tabel 3 terdapat adanya interaksi pada perlakuan G2P1, G1P1 dan G1P2, sedangkan pada perlakuan G2P2 tidak terdapat interaksi.

Tabel 3. Rata-rata Bobot Cacing Pada Kombinasi Perlakuan Media dan Pakan Terhadap Bobot Akhir Cacing Tanah Lumbricus runellus (gram)

\begin{tabular}{cccc}
\hline & \multicolumn{2}{c}{ Media (G) } & \\
\cline { 2 - 3 } Pakan (P) & Pupuk Kandang & $\begin{array}{c}\text { Kombinasi Pupuk Kandang } \\
\text { Kotoran Sapi(G1) }\end{array}$ & $\begin{array}{c}\text { Kotoran Sapi dengan Tanah } \\
\text { Gambut } \\
(\mathrm{G} 2)\end{array}$ \\
& & Rata-rata \\
\hline Ampas Tahu (P1) & $105,58 \mathrm{bc}$ & $155,77 \mathrm{~d}$ & \\
Rumen Sapi (P2) & $90,83 \mathrm{~b}$ & $47,56 \mathrm{a}$ & 69,19 \\
\hline Rata-rata & 98,20 & 101,66 & \\
\hline BNJ 5\% Gx P $=$ & 18,85 & & \\
\hline
\end{tabular}

Keterangan : Angka-angka yang diikuti oleh huruf yang sama pada kolom yangsama berbeda tidak nyata pada taraf peluang BNJ 5\%.

Berdasarkan uji lanjut pada Tabel 3 terlihat adanya interaksi antara pemberian jenis media dan pakan terhadap bobot akhir cacing tanah Lumbricus rubellus dengan rata-rata kombinasi terbaik terdapat pada perlakuan G2P1 (155,77 gram), G1P1 (105,58 gram) dan G1P2 (90,83 gram) pada bobot cacing yang mengalami peningkatan karena pada media dan pakan sangat dipengaruhi oleh kondisi dan ketersedian kandungan nutrisi yang cukup dan dapat memberikan pengaruh yang nyata, sehingga membantu pertumbuhan bobot cacingtersebut. Sedangakan kombinasi terendah terdapat pada perlakuan G2P2 (47,56 gram). Pada kombinasi terendah G2P2 hal ini diduga interaksi antara perlakuan bobot cacing mengalami penurunan bobot tubuh cacing disebabkan karena kandungan pakan kurang atau rendah protein dan nutrisi pada media tumbuh sehingga tidak mencukupi untuk pertumbuhan cacing dan dapat menyebabkan cacing menjadi kurus atau mati sehingga tidak memberi pengaruh yang nyata terhadap bobot cacing tersebut. Bobot cacing tanah Lumbricus rubellus sangat dipengaruhi oleh kondisi media dan ketersediaan nutrisi (Pangkulun, 1999 dalam Jaya, dkk 2018).

\section{Parameter pH Pupuk Organik Cair Pada Kompos Cacing Tanah Lumbricus rubellus}

Hasil analisis ragam terhadap parameter $\mathrm{pH}$ menunjukkan adanya interaksi pada kombinasi G2P1, G2P2 dan G1P1 sehingga memberikan pengaruh yang nyata terhadap nilai $\mathrm{pH}$ pupuk organik cair. Sedangkan pada perlakuan G2P2 tidak terdapat interaksi dan tidak memberi pengaruh yang nyata. Rata-rata $\mathrm{pH}$ pupuk organik cair hasil vermikompos dengan cacing tanah Lumbricus rubellus pada media dan pakan yang berbeda disajikan pada Tabel 4.

Tabel 4. Rata-rata Kombinasi pH Pupuk Organik Cair Pada Kompos Cacing Tanah Lumbricus rubellus $(\mathrm{mg} / \mathrm{l})$

\begin{tabular}{ccccc}
\hline \multirow{2}{*}{ Pakan (P) } & \multicolumn{3}{c}{ Media (G) } & Rata-rata \\
\cline { 2 - 3 } & $\begin{array}{c}\text { Pupuk Kandang } \\
\text { Kotoran Sapi } \\
(\mathrm{G} 1)\end{array}$ & $\begin{array}{c}\text { Kombinasi Media PupukKandang } \\
\text { Kotoran Sapi dengan Tanah } \\
\text { Gambut (G2) }\end{array}$ & \\
\hline Ampas Tahu (P1) & $6,47 \mathrm{~b}$ & $6,98 \mathrm{~b}$ & 6,73 \\
Rumen Sapi (P2) & $4,34 \mathrm{a}$ & $6,94 \mathrm{~b}$ & 5,64 \\
\hline Rata-rata & 5,40 & 6,96 & & \\
\hline BNJ 5\% G x P $=$ & 0,78 & & & \\
\hline
\end{tabular}

Keterangan : Angka-angka yang diikuti oleh huruf yang sama pada kolom yangsama berbeda tidak nyata pada taraf peluang BNJ $5 \%$.

Berdasarkan uji lanjut pada Tabel 4, terlihat adanya interaksi antara perlakuan media dan pakan terhadap pH pupuk organik cair kompos cacing tanah Lumbricus rubellus. Rata-rata $\mathrm{pH}$ tertinggi terdapat pada 
Kominasi perlakuanG2P1 (6,98 mg/l), G2P2 $(6,94 \mathrm{mg} / \mathrm{l})$ dan G1P1 $(6,47 \mathrm{mg} / \mathrm{l})$. pH terendah terdapat pada kombinasi perlakuan G1P2 $(4,34 \mathrm{mg} / \mathrm{l})$, hal ini diduga interaksi antara perlakuan memberikan pengaruh yang tidak nyata terhadap $\mathrm{pH}$ pupuk organik cair factor yang mempengaruhi proses pengomposan yaitu ukuran bahan, kelembapan,mikroorganisme yang bekerja, aerasi, sushu dan keasaman $\mathrm{pH}$ itu sendiri. Perbedaan $\mathrm{pH}$ tersebut terjadi karena dalam suatu media pengomposan, $\mathrm{pH}$ merupakan salah satu faktor yang mempengaruhi aktivitas mikroorganisme pada saat proses pengomposan. Proses pembalikan yang dilakukan secara berkala memiliki peran dalam mengurangi kemasaman kompos. Selama proses pembuatankompos berlangsung, asam-asam organik tersebut akan menjadi netral dan kompos menjadi matang pada kisaran pH antara 6-8 (Nurdini $d k k, 2016$ ).

\section{Senyawa Nitrat (NO3)}

Hasil analisis ragam senyawa $\mathrm{NO} 3$ menunjukkan tidak adanya interaksi pada kombinasi perlakuan G1P1, G1P2, G2P1dan G2P2 sehingga memberikan pengaruh yang tidak nyata terhadap senyawa NO3 pupuk organik cairpada kompos cacing tanah Lumbricus rubellus. Rata-rata NO3 pupuk organik cair hasil vermikompos dengan cacing tanah Lumbricus rubellus pada media dan pakan yang berbeda disajikan pada Tabel 5.

Tabel 5. Rata-rata NO3 Pupuk Organik Cair Pada Kompos Cacing Lumbricus rubellus (mg/l)

\begin{tabular}{ccccc}
\hline & \multicolumn{3}{c}{ Media (G) } & \\
\cline { 2 - 3 } Pakan (P) & $\begin{array}{c}\text { Pupuk Kandang } \\
\text { Kotoran Sapi } \\
(\text { G1) }\end{array}$ & $\begin{array}{c}\text { Kombinasi Media Pupuk } \\
\text { Kandang Kotoran Sapi dengan }\end{array}$ & Rata-rata \\
& 3,96 & 7,80 & 5,88 \\
& 5,43 & 5,08 & 5,25 \\
\hline Ampanah Tahu (P1) & 4,69 & 6,44 & \\
Rumen Sapi (P2) & & & \\
\hline Rata-rata & & & \\
\hline
\end{tabular}

Data Tabel 5, diketahui rata-rata NO3 pada perlakuan pemberian mediapupuk kandang kotoran sapi dan pakan ampas tahu G1P1 (3,96 mg/l), pemberian media pupuk kandang kotoran sapi dan pakan rumen sapi G1P2 (5,43 mg/l), pemberian kombinasi mdia pupuk kandang kotoran sapi dengan tanah gambut danpakan ampas tahu G2P1 (7,80 ml/l), pemberian kombinasi media pupuk kandang kotoran sapi dengan tanah gambut dan pakan rumen sapi G2P2 (5,80 mg/l). Pada jenis media dan pakan ditemukan bahwa data tidak memiliki pengaruh yang nyata terhadap senyawa NO3 pada pupuk organik cair hasil vermikompos dengan cacing tanah Lumbricus rubellus.

\section{Senyawa (NO2)}

Hasil analisis ragam senyawa $\mathrm{NO} 2$ menunjukkan tidak adanya interaksi pada kombinasi perlakuan G1P1, G1P2, G2P1dan G2P2 sehingga memberikan pengaruh yang tidak nyata terhadap senyawa $\mathrm{NO} 2$ pupuk organik cair pada kompos cacing tanah Lumbricus rubellus. Rata-rata NO2 pupuk organik cair hasil vermikompos dengan cacing tanah Lumbricus rubellus pada media danpakan yang berbeda disajikan pada Tabel 6.

Tabel 6. Rata-rata NO2 Pupuk Organik Cair Pada Kompos Cacing Tanah Lumbricus rubellus (mg/l)

\begin{tabular}{cccrc}
\hline & \multicolumn{3}{c}{ Media (G) } & \\
\cline { 2 - 3 } Pakan (P) & $\begin{array}{c}\text { Pupuk Kandang } \\
\text { kotoran Sapi } \\
(\mathrm{G} 1)\end{array}$ & $\begin{array}{c}\text { Kombinasi Media PupukKandang } \\
\text { Kotoran Sapi dengan Tanah } \\
\text { Gambut (G2) }\end{array}$ & Rata-rata \\
& 1,02 & 0,58 & 0,80 \\
\hline Ampas Tahu (P1) & 0,18 & 0,55 & 0,36 \\
Rumen Sapi (P2) & 0,60 & 0,56 & \\
\hline Rata-rata & & & & \\
\hline
\end{tabular}


Data Tabel 6, diketahui rata-rata $\mathrm{NO} 2$ pada perlakuan pemberian mediapupuk kandang kotoran sapi dan pakan ampas tahu G1P1 (1,02 mg/l), pemberian media pupuk kandang kotoran sapi dan pakan rumen sapi G1P2 (0,18 mg/l), pemberian kombinasi media pupuk kandang kotoran sapi dengan tanah gambut dan pakan ampas tahu G2P1 $(0,58 \mathrm{ml} / \mathrm{l})$, pemberian kombinasi media pupukkandang kotoran sapi dengan tanah gambut dan pakan rumen sapi G2P2 $(0,55 \mathrm{mg} / \mathrm{l})$. Pada jenis media dan pakan ditemukan bahwa data tidak memiliki pengaruh yang nyata terhadap senyawa $\mathrm{NO} 2$ pada pupuk organik cair hasil vermikompos dengan cacing tanah Lumbricus rubellus.

\section{Kandungan Unsur Hara Fosfor $(P)$}

Hasil analisis ragam kandungan unsur hara $\mathrm{P}$ menunjukkan tidak adanya interaksi pada kombinasi perlakuan G1P1, G1P2, G2P1dan G2P2 sehingga memberikan pengaruh yang tidak nyata terhadap pupuk organik cair pada kompos cacing tanah Lumbricus rubellus. Rata-rata kandungan unsur Ppupuk organik cair hasil vermikompos dengan cacing tanah Lumbricus rubellus pada media dan pakan yang berbeda disajikan pada Tabel 7.

Tabel 7. Rata-rata Kandungan unsur hara P Pupuk Organik Cair Pada Kompos Cacing Tanah Lumbricus rubellus (mg/l)

\begin{tabular}{cccc}
\hline & \multicolumn{3}{c}{ Media (G) } \\
\cline { 2 - 3 } Pakan (P) & $\begin{array}{c}\text { Pupuk Kandang } \\
\text { Kotoran Sapi } \\
(\mathrm{G} 1)\end{array}$ & $\begin{array}{c}\text { Kombinasi Media Pupuk } \\
\text { Kandang Kotoran Sapi dengan } \\
\text { Tanah Gambut (G2) }\end{array}$ & \\
\hline Ampas Tahu (P1) & 3,50 & 3,64 & 3,57 \\
Rumen Sapi (P2) & 4,31 & 4,10 & 4,20 \\
\hline Rata-rata & 3,90 & 3,87 & \\
\hline
\end{tabular}

Data Tabel 7, diketahui rata-rata kandungan unsur hara $\mathrm{P}$ pada pupuk organik cair kompos cacing Lumbricus rubellus dengan perlakuan pemberianmedia pupuk kandang kotoran sapi dan pakan ampas tahu G1P1 (3,50 mg/l), pemberian media pupuk kandang kotoran sapi dan pakan rumen sapi G1P2 (4,31 $\mathrm{mg} / \mathrm{l})$, pemberian kombinasi media pupuk kandang kotoran sapi dengan tanah gambut dan pakan ampas tahu G2P1 (3,64 mg/l), pemberian kombinasi media pupuk kandang kotoran sapi dengan tanah gambut dan pakan rumen sapi G2P2 $(4,10 \mathrm{mg} / \mathrm{l})$. Pada jenis media dan pakan ditemukan bahwa data tidak memiliki pengaruh yang nyata terhadap kandungan unsur hara $\mathrm{P}$ pada pupuk organik cair hasil vermikompos dengan cacing tanah Lumbricus rubellus, hal ini dapat dipengaruhi oleh dalam proses pengomposan banyak hal seperti media atau bahan kompos, bioaktivator, waktu pengomposan dan faktor lingkungan lainnya. Suatu pengomposan dapat berjalan dengan baik jika beberapa ketentuan dalam pengomposan terpenuhi. Pemberian bioaktivator merupakan salah satu faktor yang mempengaruhi proses pengomposan karena dapat mempercepat proses pengomposan. Menurut Nugroho (2014), lama waktu pengomposan tergantung pada karakteristik bahan yang dikomposkan, metode pengomposan yang digunakan atau tanpa aktivator pengomposan. Aktivator yang digunakan dalam pengomposan pada penelitian ini adalah cacing tanah Lumbricus rubellus. Hal ini mendukung bahwa cacing tanah Lumbricus rubellus lebih menyukai tanah yang mengandung bahan organik yang tinggi. Menurut Nofyan (2000) menyatakanbahwa kemampuan cacing tanah dalam mengonsumsi bahan organik sebagai pakan sangat dipengaruhi oleh ketersediaan bahan organik yang disukai serta kandungan kimianya.

\section{Kandungan Unsur Hara Kalium}

Hasil analisis ragam kandungan unsur hara $\mathrm{K}$ menunjukkan pada faktor tunggal perlakuan G1 berpengaruh nyata. Sedangkan pada faktor tunggal perlakuan G2 tidak berpengaruh nyata pada kandungan unsur hara $\mathrm{K}$ pupuk organik cair pada kompos cacing tanah Lumbricus rubellus. Rata-rata kandungan unsur $\mathrm{K}$ pupuk organik cair hasil vermikompos dengan cacing tanah Lumbricus rubellus pada media dan pakan yang berbeda disajikan pada Tabel 8 . 
Tabel 8. Rata-rata Kandungan K Pupuk Organik Cair Pada Kompos Cacing Tanah Lumbricus rubellus $(\mathrm{mg} / \mathrm{l})$

\begin{tabular}{cccc}
\hline & \multicolumn{3}{c}{ Media (G) } \\
\cline { 2 - 3 } Pakan (P) & $\begin{array}{c}\text { Pupuk Kandang } \\
\text { Kotoran Sapi } \\
\end{array}$ & $\begin{array}{c}\text { Kombinasi Media Pupuk } \\
\text { Kandang Kotoran Sapi dengan }\end{array}$ & Rata-rata \\
& & $\begin{array}{c}\text { Tanah Gambut } \\
(\mathrm{G} 2)\end{array}$ & \\
\hline Ampas Tahu (P1) & 276,14 & 248,67 & 262,40 \\
Rumen Sapi (P2) & 262,34 & 248,06 & 255,20 \\
\hline Rata-rata & $269,23 \mathrm{~b}$ & $248,36 \mathrm{a}$ & \\
\hline BNJ 5\% G $=11,78$ & & & \\
\hline
\end{tabular}

Keterangan : Angka-angka yang diikuti oleh huruf yang sama pada kolom yang sama menunjukan tidak berbeda nyata pada taraf peluang BNJ $5 \%$.

Data Tabel 8, diketahui data analisis unsur $\mathrm{K}$ pupuk organik cair kompos cacing tanah Lumbricus rubellus memiliki hasil analisis ragam bahwa faktor tunggal perlakuan media $\mathrm{G}$ berpengaruh nyata, sedangkan pada faktor tunggal perlakuan pakan $\mathrm{P}$ dan antara perlakuan $\mathrm{G}$ dan $\mathrm{P}$ tidak berpengaruh nyata terhadap unsur K. pada faktor tunggal perlakuan G1 berpengaruh nyata, sedang faktor tunggal perlakuan G2 tidak berpengaruh nyata bahwa pada jumlah cacing tanah terbanyak dan waktu pengomposan terlama menghasilkan kandungan NPK tertinggi. Penggunaan cacing tanah berpengaruh dalam mempercepat waktu pengomposan. Kerjasama antara cacing tanah dan mikroorganisme memberi dampak proses penguraian berjalan dengan baik walaupun sebagian besar proses penguraian dilakukan oleh mikroorganisme terlebih dahulu diuraikan oleh cacing,sehingga kerja mikroorganisme lebih cepat dan efektif (Husain $d k k, 2014$ ).

\section{Senyawa Amoniak (NH3)}

Hasil analisis ragam senyawa $\mathrm{NH} 3$ menunjukkan tidak adanya interaksi pada kombinasi perlakuan G1P1, G1P2, G2P1dan G2P2 sehingga memberikan pengaruh yang tidak nyata terhadap senyawa NH3 pupuk organik cairpada kompos cacing tanah Lumbricus rubellus. Rata-rata $\mathrm{NH} 3$ pupuk organik cair hasil vermikompos dengan cacing tanah Lumbricus rubellus pada media danpakan yang berbeda disajikan pada Tabel 9.

Tabel 9. Rata-rata NH3 Pupuk Organik Cair Pada Kompos Cacing Tanah Lumbricus rubellus (mg/l)

\begin{tabular}{ccccc}
\hline & \multicolumn{3}{c}{ Media (G) } & \\
\cline { 2 - 4 } Pakan (P) & $\begin{array}{c}\text { Pupuk Kandang } \\
\text { Kotoran Sapi } \\
(\mathrm{G} 1)\end{array}$ & $\begin{array}{c}\text { Kombinasi Media PupukKandang } \\
\text { Kotoran Sapi dengan Tanah } \\
\text { Gambut (G2) }\end{array}$ & Rata-rata \\
\hline Ampas Tahu (P1) & 0,00 & 0,05 & 0,03 \\
Rumen Sapi (P2) & 0,00 & 0,00 & 0,00 \\
\hline Rata-rata & 0,00 & 0,03 & \\
\hline
\end{tabular}

Pada Tabel 9, diketahui rata-rata NO3 pada perlakuan pemberian media pupuk kandang kotoran sapi dan pakan ampas tahu G1P1 $(0,00 \mathrm{mg} / \mathrm{l})$, pemberian media pupuk kandang kotoran sapi dan pakan rumen sapi G1P2 $(0,00 \mathrm{mg} / \mathrm{l})$, pemberian kombinasi media pupuk kandang kotoran sapi dengan tanah gambut dan pakan ampas tahu G2P1 $(0,05 \mathrm{ml} / \mathrm{l})$, pemberian kombinasi media pupukkandang kotoran sapi dengan tanah gambut dan pakan rumen sapi G2P2 $(0,00 \mathrm{mg} / \mathrm{l})$. Pada jenis media dan pakan ditemukan bahwa data tidak memiliki pengaruh yang nyata terhadap senyawa $\mathrm{NH} 3$ pada pupuk organik cair hasil vermikompos dengan cacing tanah Lumbricus rubellus. 


\section{Kandungan Unsur Hara Nitrogen $(N)$}

Hasil analisis ragam kandungan unsur hara $\mathrm{N}$ menunjukkan tidak adanya interaksi pada kombinasi perlakuan G1P1, G1P2, G2P1dan G2P2 sehingga memberikan pengaruh yang tidak nyata terhadap kandungan unsur haraN pupuk organik cair pada kompos cacing tanah Lumbricus rubellus. Rata-rata kandungan unsur hara $\mathrm{N}$ pupuk organik cair hasil vermikompos dengan cacing tanah Lumbricus rubellus pada media dan pakan yang berbeda disajikan pada Tabel 10 .

Tabel 10. Rata-rata Kandungan Unsur Hara N Pupuk Organik Cair Pada KomposCacing Tanah Lumbricus rubellus $(\mathrm{mg} / \mathrm{l})$

\begin{tabular}{|c|c|c|c|}
\hline \multirow{2}{*}{ Pakan (P) } & \multicolumn{2}{|c|}{ Media (G) } & Rata-rata \\
\cline { 2 - 4 } & $\begin{array}{c}\text { Pupuk Kandang } \\
\text { Kotoran Sapi } \\
(\mathrm{G} 1)\end{array}$ & $\begin{array}{c}\text { Kombinasi Media Pupuk } \\
\text { Kandang Kotoran Sapi } \\
\text { dengan Tanah Gambut (G2) }\end{array}$ & \\
\hline Ampas Tahu (P1) & 4,98 & 8,43 & 6,7 \\
\hline Rumen Sapi (P2) & 5,61 & 5,63 & 5,61 \\
\hline Rata-rata & 5,29 & 7,03 & \\
\hline
\end{tabular}

Pada Tabel 10, diketahui rata-rata kandungan unsur hara Nitrogen pupuk organik cair pada cacing tanah Lumbricus rubellus dengan perlakuan pemberian media pupuk kandang kotoran sapi dan pakan ampas tahu G1P1 $(4,98) \mathrm{mg} / \mathrm{l}$, pemberian media pupuk kandang kotoran sapi dan pakan rumen sapi G1P2 $(5,62$ $\mathrm{mg} / 10$, pemberian media kombinasi pupuk kandang kotoran sapi dan tanah gambut dengan pakan ampas tahu G2P1 $(8,43 \mathrm{mg} / \mathrm{l})$, pemberian media kombinasi pupuk kandang kotoran sapi dan pakan ampas tahu G2P2 $(5,63 \mathrm{mg} / \mathrm{l})$. Pada jenis media dan pakan ditemukan bahwa data tidak memiliki pengaruh yang nyata terhadap Nitrogen pada pupuk organik cair hasil vermikompos dengan cacing tanah Lumbricus rubellus, hal ini telah sejalan menurut Hanafi'ah (2004) dalam Pramaswari (2011), bahwa dalam proses mineralisasi senyawa nitrogen terjadi 3 tahapan yaitu: aminasi dimana gas amoniak hasil mineralisai apabila tidak segera mengalami amonifikasi atau tidak dipakai oleh mikroorganisme akan segera menguap keudara, amonifikasi yaitu sebagian besar amoniak akan berubah menjadi NH4 + akibat adanya proses ikatan elektron yang kuat dengan ion - ion $\mathrm{H}+$, nitrifikasi dimana nitrat digunakan oleh organisme anaerobik untuk respirasinya sebagai pengganti oksigen. Mikroorganisme selain merombak bahan organik menjadi yang lebih sederhana, juga menggunakan bahan organik untuk aktivitas metabolisme hidupnya (Marsiningsih, 2015).

\section{Suhu Pupuk Organik Cair Pada Kompos Cacing Tanah Lumbricus rubellus}

Hasil analisis ragam suhu pagi hari menunjukkan pada faktor tunggal perlakuan G2 dan P2 berpengaruh nyata. Sedangkan pada faktor tunggal perlakuan G1dan P1 tidak berpengaruh nyata pada suhu sore hari pupuk organik cair pada kompos cacing tanah Lumbricus rubellus. Rata-rata suhu suhu pupuk organik cair pada kompos cacing tanah Lumbricus rubellus pagi hari selama 35 hari pengomposan pupuk organik cair hasil vermikompos dengan cacing tanah Lumbricus rubellus pada media dan pakan yang berbeda disajikan pada Tabel 11 .

Tabel. 11. Rata-rata Suhu Pagi Hari Pupuk Organik Cair Pada Kompos Cacing Tanah Lumbricus rubellus

\begin{tabular}{cccc}
\hline & \multicolumn{3}{c}{ Media (G) } \\
\cline { 2 - 3 } Pakan (P) & $\begin{array}{c}\text { Pupuk Kandang } \\
\text { Kotoran Sapi } \\
(\mathrm{G} 1)\end{array}$ & $\begin{array}{c}\text { Kombinasi Media Pupuk } \\
\text { Kandang Kotoran Sapi } \\
\text { dengan Tanah Gambut (G2) }\end{array}$ & Rata-rata \\
\hline Ampas Tahu (P1) & 26,35 & 26,45 & $26,40 \mathrm{a}$ \\
Rumen Sapi (P2) & 26,48 & 26,55 & $26,51 \mathrm{~b}$ \\
\hline Rata-rata & $26,41 \mathrm{a}$ & $26,50 \mathrm{~b}$ & \\
\hline BNJ 5\% G dan P $=0,5$ & & &
\end{tabular}

Keterangan : Angka-angka yang diikuti oleh huruf yang sama pada kolom yang sama menunjukkan tidak berbeda nyata pada tara peluang BNJ taraf $5 \%$. 
Dari Tabel 11, diketahui rata-rata suhu pagi hari selama 35 hari pengomposan pupuk organik cair kompos cacing tanah Lumbricus rubellus pada jenis media dan pakan memberikan pengaruh nyata terhadap suhu di pagi hari. Jenis media dan pakan memiliki suhu yang berbeda pada kompos pupuk organik cair cacing tanah Lumbricus rubelllus, dimana pada perlakuan media G2 dengan rata-rata suhu $\left(26,50{ }^{\circ} \mathrm{C}\right)$ dan pada perlakuan pakan $\mathrm{P} 2$ dengan rata-rata suhu $\left(26,51^{\circ} \mathrm{C}\right)$ menghasilkan suhu terbaik dibandingkan jenis perlakuan media G1 rata-rata suhu $\left(26,41^{\circ} \mathrm{C}\right)$ dan perlakuan jenis pakan P1 memiliki rata-rata suhu $\left(26,40^{\circ} \mathrm{C}\right)$. Menurut (Isroi, 2008) variasi kompos tersebut dapat terjadi karena pada saat sebagian besar bahan organik kompos telah terurai, maka suhu akan menurun. Menurut setyorini (2006), semakin tinggi volume timbunan kompos, maka semakin besar isolasi panas. Timbunan yang terlalu dangkal akan mudah untuk kehilangan panas karena bahan tidak cukup untuk menahan panas.

Hasil analisis ragam menunjukkan pada faktor tunggal perlakuan G2 berpengaruh nyata. Sedangkan pada faktor tunggal perlakuan G1 tidak berpengaruh nyata pada suhu siang hari pupuk organik cair pada kompos cacing tanah Lumbricus rubellus. Rata-rata Suhu siang hari pupuk organik cair hasil vermikompos dengan cacing tanah Lumbricus rubellus pada media dan pakan yang berbeda disajikan pada Tabel 12.

Tabel. 12. Rata-rata Suhu Siang Hari Pupuk Organik Cair Pada Kompos Cacing Tanah Lumbricus rubellus

\begin{tabular}{cccc}
\hline & \multicolumn{2}{c}{ Media (G) } \\
\cline { 2 - 3 } Pakan (P) & $\begin{array}{c}\text { Pupuk Kandang } \\
\text { Kotoran Sapi } \\
\end{array}$ & $\begin{array}{c}\text { Kombinasi Media Pupuk } \\
\text { Kandang Kotoran Sapi dengan }\end{array}$ & Rata-rata \\
& & $\begin{array}{c}\text { Tanah Gambut } \\
(\mathrm{G} 2)\end{array}$ & \\
\hline Ampas Tahu (P1) & 28,90 & 29,17 & 29,03 \\
Rumen Sapi (P2) & 28,97 & 29,36 & 29,16 \\
\hline Rata-rata & 28,93 a & $29,26 \mathrm{~b}$ & \\
\hline BNJ 5\% G = 0,3 & & \\
\hline gan : Angka-angka yang diikuti oleh huruf yang sama pada kolom yang sama menunjukan tidak berbeda
\end{tabular}

Data Tabel 12, diketahui rata-rata suhu siang hari selama 35 hari pengomposan pupuk organik cair kompos cacing tanah Lumbricus rubellus pada jenis media dan pakan memberikan pengaruh nyata terhadap suhu di siang hari. Jenis media dan pakan memiliki suhu yang berbeda pada kompos pupuk organik cair cacing tanah Lumbricus rubelllus, dimana pada perlakuan media G2 dengan rata-rata suhu $\left(29,26^{\circ} \mathrm{C}\right)$ menghasilkan suhu terbaik dibandingkan jenis perlakuan media G1 dengan rata-rata suhu $\left(26,41^{\circ} \mathrm{C}\right)$. Menurut (Isroi, 2008) variasi kompos tersebut dapat terjadi karena pada saat sebagian besar bahan organik kompos telahterurai, maka suhu akan menurun. Menurut setyorini (2006), semakin tinggi volume timbunan kompos, maka semakin besar isolasi panas. Timbunan yang terlalu dangkal akan mudah untuk kehilangan panas karena bahan tidak cukup untuk menahan panas.

Hasil analisis ragam suhu sore hari menunjukkan tidak adanya interaksi pada kombinasi perlakuan G1P1, G1P2, G2P1dan G2P2 sehingga memberikanpengaruh yang tidak nyata terhadap suhu sore hari pupuk organik cair pada kompos cacing tanah Lumbricus rubellus. Rata-rata suhu sore hari pupuk organik cair hasil vermikompos dengan cacing tanah Lumbricus rubellus pada media dan pakan yang berbeda disajikan pada Tabel 13. Data Tabel 13, diketahui data rata-rata suhu sore hari selama 35 hari pengomposan pupuk organik cair hasil vermikompos cacing tanah Lumbricusrubellus tidak berbeda nyata pada perlakuan media dan pakan. Hal inimenunjukkan bahwa semua kompos sudah matang. Perubahan suhu dalam pengomposan merupakan salah satu indikator untuk mengetahui proses dekomposisi bahan organik (bahan kompos) berjalan baik. Suhu pupuk organik cair yang dihasilkan dalam penelitian ini diketahui tidak menunjukkan pengaruh yang nyata. Hal ini dikarenakan suhu pada akhir kompos telah mencapai tingkat kematangan pada semua perlakuan yang telah diuji cobakan. Suhu kematangan pupuk organik cair yaitu telah sama dengan suhu air tanah $\left(28^{\circ} \mathrm{C}-30^{\circ} \mathrm{C}\right)$ (Srihartati, 2010). Semakin besar tumpukan panas yang didapat dalam tumpukan semakin besar sehingga suhu tumpukan semakin tinggi (Wahyono,2003). 
Tabel. 13. Rata-rata Suhu Sore Hari Selama 35 Hari Pupuk Organik Cair Pada Kompos Cacing Tanah Lumbricus rubellus

\begin{tabular}{|c|c|c|c|}
\hline \multirow[b]{2}{*}{ Pakan (P) } & \multicolumn{2}{|r|}{ Media (G) } & \multirow[b]{2}{*}{ Rata-rata } \\
\hline & $\begin{array}{l}\text { Pupuk Kandang } \\
\text { Kotoran Sapi } \\
\text { (G1) }\end{array}$ & $\begin{array}{c}\text { Kombinasi Media Pupuk } \\
\text { Kandang Kotoran Sapi } \\
\text { dengan Tanah Gambut(G2) }\end{array}$ & \\
\hline Ampas Tahu (P1) & 29,35 & 29,01 & 29,18 \\
\hline Rumen Sapi (P2) & 29,44 & 29,51 & 29,47 \\
\hline Rata-rata & 29,39 & 29,25 & \\
\hline
\end{tabular}

\section{Kesimpulan}

Berdasarkan hasil penelitian ini, maka dapat disimpulkan sebagai berikut :

1. Terdapat interaksi antara jenis media dan jenis pakan terhadap kualitas pupuk organik cair pada kompos cacing tanah Lumbricus rubellus terhadap parameter bobot akhir cacing tanah Lumbricus rubellus dengan kombinasi terbaik terdapat pada perlakuan media kombinasi pupuk kandang kotoran sapi dengan tanah gambut (155,77 gram) dan pada parameter $\mathrm{pH}$.

2. Terdapat pengaruh yang nyata pada jenis media terhadap kualitas hasil pupuk organik cair pada kompos cacing tanah Lumbricus rubellus tehadap parameter K faktor tunggal perlakuan media pupuk kandang kotoran sapi $(269,23 \mathrm{mg} / \mathrm{l})$ dan terhadap parameter suhu di pagi hari pada faktor tunggal perlakuan media kombinasi pupuk kandang kotoran sapi dengan tanah gambut $\left(26,50{ }^{\circ} \mathrm{C}\right)$, dan siang hari terdapat pada faktor tunggal perlakuan media kombinasi pupuk kandang kotoran sapi dengan tanah gambut $\left(29,26^{\circ} \mathrm{C}\right)$. Sedangkan yang tidak berpengaruh nyata terhadap parameter senyawa $\mathrm{NO} 3$, senyawa $\mathrm{NO} 2$, unsur $\mathrm{P}$, senyawa $\mathrm{NH} 3$, dan unsur $\mathrm{N}$.

3. Terdapat pengaruh yang nyata pada jenis pakan terhadap kualitas hasil pupuk organik cair dari kompos cacing tanah Lumbricus rubellus terhadap parameter suhu dipagi hari pada faktor tunggal perlakuan pakan rumen sapi $\left(26,51^{\circ} \mathrm{C}\right)$.

\section{Daftar Pustaka}

Abbot, I and C.A. Parker.1981. Interactions Between Earthworms and Their SoilEnvironment, Soil Biol and Biochem, 191-197

Anderson, J.M. 1994. Functional Atribute of Biodiversity in Land Use Systems.In D.J. Greenland and I. Szabolez (Eds). Soil Resilience and Sustainable Land Use. CAB International. New York.

Buck, C., M. Langmaack, and S. Schrader. 1999. Nutrient content of earthworm cast influenced by different mulch types. Eur.J.Soil.Biol 55:23-30

Djuarnani, N., Kristian, dan Setiawan. B. D,. 2005. Cara Cepat Membuat Kompos. Cetakan Pertama. Agromedia Pusaka. Jakarta

Dominguez. J and C. A. Edwards, 2011. "Relationships between composting and vermicomposting," in Vermiculture Technology Earthworms, OrganicWastes, and Environmental Management, C. A. Edwards, N. Q. Arancon, and R. Sherman, Eds., pp. 11-26, Taylor \& Francis, New York, NY,USA

Edwards, C.A.and J.R. Lovty, (1977). Biology and Earthworm. Champman and Hall Ltd. London.

Gaddie, R. E and D. E. Douglas, 1977.Earthworm for Ecology and Profit. Vol II. Bookworm Publishing Company Ontario, California

Gajalakshmi S, Ramasamy E.E, Abbasi S.A, 2002. Vermicomposting of Paper Waste With the Anecic Eartworn Lampiri mauritii Kingburg. Indian Chem Technol 9:306-311

Hanafiah,K. A., 2004. Dasar - dasar Ilmu Tanah. Palembang. 
Hardjowigeno, S. 1986. Genesis dan Klasifikasi Tanah. Jurusan Tanah, Fakultas Pertanian IPB: Bogor

Husain, D. Sukarsono, dan Mahmudati, N,. 2014. Pengaruh jumlah cacing tanah (Lumbricus rubellus) dan Waktu Pengomposan terhadap Kandungan NpkLimbah Media Tanam Jamur Tiram Sebagai Bahan Ajar Biologi. Jurnal Pendidikan Biologi Indonesia. Volume 1 nomor 1. (halaman 1-8)

Isroi. 2008. Kompos. Bogor: Balai Penelitian Bioteknologi Perkebunan Indonesia.

Jaya A, Lautt B.S, Mulahartani, R, Kamilah, \& Lautt, B.S (2018). Pengaruh Bobot Koloni Dan Jenis Pakan Terhadap Kualitas Pupuk Organik Cair Kompos Cacing Lumbricus rubellus. Jurnal Agri Peat. Vol. 19 No. $2: 84-93$.

Lingga, P. dan Marsono, 2000. Petunjuk Penggunaan Pupuk. Penebar Swadaya. Jakarta

Marsiningsih, Ni Wayan. 2015. Analisis Kualitas Larutan Mol Berbasis Ampas Tahu. Jurnal Agroekoteknologi Tropika. Fakultas Pertanian. Universitas Udayana. Vol.4. No.3.

Mashur. 2001. Vermikompos Pupuk Organik Berkualitas dan RamahLingkungan”.Instalasi Penelitian dan Pengkajian Teknologi Pertanian Badan Penelitian dan Pengembangan Pertanian. Mataram

Mulat, T. 2003. Membuat dan Manfaat Kascing Pupuk Organik Berkualitas. Agromedia Pustaka. Jakarta

Munroe G. 2003. Manual of On-Farm Vermicomposting and verculture.Organic Agriculture Centre of Canada.

Musnamar, E. I., 2007. Pupuk Organik : Cair dan Padat, Pembuatan, Aplikasi. Penebar Swadaya. Jakarta.

Nofyan, E. 2000. Studi Berbagai Macam Feses Hewani Terhadap Laju Konsumsi dan Produksi kokon Cacing Tanah P. Javanica Gates Prosiding Bks, PTNBidang Mipa, UNRI Pekanbaru

Noviansyah. N.F, Kurnani.B.A, dan Sudiarto.2015. Pengaruh Perbandingan Limbah Peternakan Sapi Perah dan Limbah Kubis (Brassica oleracea) Pada Vermicomposting terhadap Biomassa Cacing Tanah (Lumbricusrubellus) Dan Biomassa Kascing. Jurnal Universitas Padjadjaran. Bandung

Nugroho, P. 2014. Panduan Membuat Pupuk Kompos Cair. Yogyakarta: Pustaka Baru Press.

Nurdini. L, Amanah. R.D, dan Utami.A.U,.2016. Pengolahan Limbah Sayur Kol menjadi Pupuk Kompos dengan Metode Takakura. Yogyakarta. Prosiding Seminar Nasional Teknik Kimia. ISSN 1693-4393

Pangkulun. 2010. Usaha Ternak Cacing Tanah Lumbricus rubellus, Penebar Swadaya, Jakarta

Pangkulun. R. 1999. Sukses Beternak Cacing Tanah Lumbricus rubellus. Penebar Swadaya. Jakarta

Paoletti MG, Favretta MR, Stinner SB, Purrington FF, and Bater JE. 1991.Invertebrates as bioindicator of soil use.

Piay, S.S, Romdon, A.S, Paryono, T.J, dan Samijan. 2012. Pertanian Organik. Balai Pengkajian Teknologi Pertanian Jawa Tengah.

Pramaswari, Ida Ayu Ari. 2011. Kombinasi Bahan Organik Rasio C:N PadaPengolahan Lumpur (Sludge) Limbah Pencelupan. Jurusan Kimia. FMIPA. Univarsitas Udayana.

Raihan. 2002. Pengaruh Bahan Organik terhadap Sifat Fisik dan Kimia Tanah, serta Hasil Jagung di Lahan Lebak. Prosiding Seminar Nasional Sumber Daya Lahan. Pusat Penelitian dan Pengembangan Tanah dan Agroklimat,Bogor.

Rozaq, A. dan Novianto, G. 2010. Pemanfaatan Tanaman Enceng Gondok Sebagai Pupuk Cair. Skripsi. Jatim: Jurusan Teknik Kimia Fakultas Teknologi Industri Universitas Pembangunan Nasional "Veteran". Jawa Timur. 
Sathianarayanan. A. and Khan. B, 2008."An Eco-Biological Approach for recource Recycling and Pathogen (Rhizoctoniae solani Kuhn) Suppresion". Journal of Enviromental Protection Science, Vol.2, (36-39)

Setiadji, B. dan Hartati. 2012. Aplikasi Pupuk Bokashi dan Pupuk Organik Cair Berbasis Azolla Microphylla pada Tanaman Pakcoy (Brassica chinensis L.). Pascasarjana, Universitas Jendral Sudirman. Purwokerto.

Setyorini, D., Rasti S., dan Ea Kosman A. 2006. Kompos. Bogor: Balai Besar Litbang Sumberdaya Lahan Pertanian Badan Penelitian dan Pengembangan Pertanian.

Simanjuntak dan Waluyo, D. 1992. Cacing Tanah, Budidaya, dan Pemanfaatannya. Penerbit Swadaya, Jakarta.

Sriharti, Salim T. 2010. Pemanfaatan Sampah Taman (Rumput-rumputan) untuk Pembuatan Kompos. Prosiding Seminar Nasional Teknik Kimia "Kejuangan". ISSN 1693-4393. Balai Besar Pengembangan Teknologi Tepat Guna LIPI, Yogyakarta.

Sudiarto, B.2013 Potensi, Efisiensi dan Standarisasi Penggunaan Pupuk Organik Kascing Dalam Meningkatkan Produktivitas Pertanian. Diakses tanggal 20 Oktober 2016

Sugiharto, D. 2006. Kecepatan Dekomposisi Sampah Organik Pasar Kota Batu serta Kandungan NPK Kompos dengan Metode Vermikompos dan EM4. Skripsi tidak diterbitkan. Malang: Fakultas Keguruan dan ilmu pendidikan Universitas Muhammadiyah Malang.

Suin, N. M. 1997. Ekologi Hewan Tanah. Bumi Aksara. Jakarta.

Tachibana, H. 2000. Water Analysis. 4th Edition. The Hikkaido Blanch of Japan Society of Analitical Chemistry Kagako Dajin Publishing C. Japanese

Wahyono, Sri Firman L., Sahwan, dan Feddy S. 2003. Mengolah Sampah Menjadi Kompos Sistem Open Windrow Bergulir Skala Kawasan. Jakarta: Badan Pengkajian dan Penerapan Teknologi

Wiryono. 2006. Pengaruh Pemberian Serasah dan Cacing Tanah Terhadap Pertumbuhan Tanaman Lamtoro Dan Turi Pada Media Tanam Tanah Bekas Penambangan Batu Bara. Bengkulu : Universitas Bengkulu.

Wood, G.A.R. 1989. Cocoa. Third Edition. Longman Group Limited. London.

Wulandari, D. 2000. Pertumbuhan dan Perkembangbiakan Cacing Tanah Eisenia foetida savigny Dalam Media Kotoran Sapi yang Mengandung Limbah Jamur Tiram.Skripsi. Jurusan Biologi. FMIPA. IPB. Bogor. 1-7

Yang. J. E. O, skogley, B. E. Schaff and J. J. Kim. 1998. A. Simple Spectrophotometric Oetermination of nitrate in water. Resin and Soil extracts. SS Aj. G2: 1108 - 1115 